\title{
Early development in the mouth-brooding cichlid fish Satanoperca pappaterra (Perciformes: Cichlidae)
}

\author{
Taise Miranda Lopes ${ }^{1}$, Fernando Garcia de Oliveira ${ }^{1}$, Andréa Bialetzki ${ }^{1,2}$ \& \\ Angelo Antonio Agostinho ${ }^{1,2}$ \\ 1. Universidade Estadual de Maringá (UEM), Departamento de Biologia (DBI), Programa de Pós-Graduação em \\ Ecologia de Ambientes Aquáticos Continentais (PEA), Av. Colombo, 5790, CEP 87020-900, Maringá, Paraná, Brazil; \\ taisemlopes@gmail.com, fgoliveira.bio@gmail.com \\ 2. Núcleo de Pesquisa em Ictiologia, Limnologia e Aquicultura (NUPELIA), Av. Colombo, 5790, Bloco H90, CEP \\ 87020-900, Maringá, Paraná, Brazil; bialetzki@nupelia.uem.br, agostinhoaa@nupelia.uem.br
}

Received 03-IV-2014. Corrected 11-VIII-2014. Accepted 09-IX-2014.

\begin{abstract}
The Neotropical region exhibits the largest diversity of fish worldwide; however, little is known about the early development of fish species from this region. Therefore, to contribute to this knowledge, this study aimed to morphologically describe the early stages of development (eggs, larvae and juveniles) of S. pappaterra using morphometric and meristic traits, and to assess changes in growth rates throughout larval and juvenile development by analyzing the relationships between various morphometric traits using analytical regression models. Both juvenile and adult individuals with mouth-brooded offspring were collected along the basins of the Cuiabá and Manso Rivers in the state of Mato Grosso, Brazil between March 2000 and March 2004. After the adults were identified, the offspring were classified according to its stage (embryonic, larval or juvenile period), and various morphometric and meristic variables were individually measured (when possible). The eggs of this species are yellow in color, oval shaped, show dendritic pigmentation within their yolk, have small to moderately sized perivitelline spaces and lack a mucous membrane and oil droplets. The horizontal and vertical diameters of the sample yolks ranged from $1.43 \mathrm{~mm}$ to $2.70 \mathrm{~mm}$ and $1.05 \mathrm{~mm}$ to $1.68 \mathrm{~mm}$, respectively. The standard length of the larval period varied from $4.30 \mathrm{~mm}$ to $7.16 \mathrm{~mm}$, and the standard length of the juvenile period varied from $10.29 \mathrm{~mm}$ to $24.57 \mathrm{~mm}$. Larvae exhibit yolk sacs with internal dendritic pigmentation and dark punctate pigmentation in the dorsal and ventral body regions, whereas irregular transverse spots along the flanks are observed during the juvenile period. Adhesive organs are only present during the yolk-sac stage and at the beginning of the flexion stage. The mouth is terminal during all stages of development. The myomere number varied from 22 to 29 ( 9 to 16 pre-anal and 10 to 16 post-anal), and the maximal numbers of fin rays and spines were as follows: dorsal, XVI+10; anal, IV+8; pectoral, 16; and pelvic, I+8. Growth analyses identified periods of important change in larval morphology (i.e., metamorphosis), particularly during the flexion and post-flexion stages and in juveniles. Therefore, the morphological development of $S$. pappaterra is consistent with the ecological requirements of this species, which primarily occurs in structured lentic environments with aquatic macrophytes. Rev. Biol. Trop. 63 (1): 139-153. Epub 2015 March 01.
\end{abstract}

Key words: ontogeny, eggs, larvae, fish, Pantanal eartheater, Paraguay River basin.

The greatest difficulty inherent to the study of freshwater ichthyoplankton is properly identifying fish eggs and larvae in their natural environments. This difficulty stems largely from the significant morphological similarities between different taxonomic groups during early stages of development (Bialetzki,
Sanches, Baumgartner, \& Nakatani, 1998) and because species spawn in the same areas at the same times of the year (Nakatani et al., 2001). Hence, the taxonomic characterization of early fish development could help us to better understand the ecological relationships between species during development within their natural 
environments, which could yield tools for more effective environmental assessments (Oliveira, Bialetzki, Gomes, Santin, \& Taguti, 2012).

Cichlidae is the second largest of the 160 characterized families within the order Perciformes, and it is composed of nearly 1300 species worldwide and approximately 291 in South America alone (Kullander, 1998). Fish from this family exhibit parental care (generally performed by the female) and are divided into two groups: substrate spawners, which attach their eggs to a substrate and exhibit parental care by both parents, and mouth-brooders, which carry their offspring in their mouths (Ribbink, 1990). Among the substrate spawners, early development has been described in a number of species, including Cichlasoma nigrofasciatum (Gunther, 1868) (Martinez \& Murillo, 1987); Cichlasoma gadovii (Regan, 1905) (Cabrera, Murillo, \& Mora, 1988); Cichlasoma dimerus (Heckel, 1840) (Meijide \& Guerrero, 2000); Astronotus ocellatus (Agassiz, 1831) (Nakatani et al., 2001; Paes, Makino, Vasquez, Fernandes, \& Nakaghi, 2011); Archocentrus myrnae (Loiselle, 1997) (Puigcerver, 2007); Amphilophus rostratus (Gill, 1877) (Molina, 2008); Apistogramma cacatuoides (Hoedeman, 1951) (Alves, Rojas, \& Romagnosa, 2009); Hypsophrys nicaraguensis (Günther, 1864) (Molina, 2011); and Pterophyllum scalare (Schultze, 1823) (Korzelecka-Orkisz et al., 2012). In contrast, early development in Neotropical mouth-brooders has not yet been described. Differences in the dynamics of larval and post-larval development between these two groups have been noted not only in terms of external morphology but also in terms of the maturation of several vital organs (Fishelson, 1995). According to Fishelson, the offspring of substrate spawners generally grow much faster and become self-sufficient long before mouthbrooded individuals of similar stages.

Satanoperca pappaterra (Heckel, 1840), which is commonly known as the Pantanal eartheater and locally known as 'cará' or 'acará,' is a mouth-brooding endemic species from the Amazon Basin (Rio Guaporé) and upper Paraguay River (Kullander, 2003). Within the
Amazon Basin, this species co-occurs with four other species of the same genus (Satanoperca acuticeps (Heckel, 1840), Satanoperca daemon (Heckel, 1840), Satanoperca jurupari (Heckel, 1840) and Satanoperca lilith (Kullander \& Ferreira, 1988), and none of these species has been characterized with respect to their early stages of development. Considering the high degree of morphological similarity within this genus as well as the spatial co-occurrence, comparative studies are required to taxonomically identify these fish during their early development. Therefore, the aims of this study were to (i) morphologically describe the early stages (eggs, larvae and juveniles) of S. pappaterra using morphometric and meristic traits and (ii) assess changes in the growth rates throughout larval and juvenile development by analyzing the relationships between various morphometric traits using analytical regression models.

\section{MATERIALS AND METHODS}

Study site: The samples used in this study were collected between March 2000 and March 2004 at different locations along the Cuiabá and Manso river basins $\left(\mathrm{P} 1=14^{\circ} 48^{\prime} 27^{\prime \prime} \mathrm{N}\right.$ $55^{\circ} 38^{\prime} 28^{\prime \prime} \mathrm{W}$; P2=14둘' $22^{\prime \prime} \mathrm{N}-55^{\circ} 46^{\prime} 28^{\prime \prime} \mathrm{W}$; $\mathrm{P} 3=14^{\circ} 57^{\prime} 07^{\prime \prime} \mathrm{N}-55^{\circ} 42^{\prime} 59^{\prime \prime} \mathrm{W}$; P4=15'06'50"

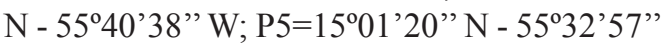
W) (Fig. 1), both of which are part of the Paraguay River hydrological basin.

Sampling: Both juveniles and mouthbrooding adults carrying eggs and/or larvae were collected using seining nets $(20 \mathrm{~m}$ length, $1 \mathrm{~cm}$ mesh size). After capture, the adults released their offspring, which were immediately collected and placed into polyethylene bottles and fixed with $4 \%$ formaldehyde buffered with calcium carbonate.

\section{Characterization of developmental stag-} es: The collected individuals were separated into embryonic (early cleavage, early embryo and tail-free stages), larval (yolk-sac, flexion and post-flexion stages) and juvenile periods in accordance with the classifications proposed by 


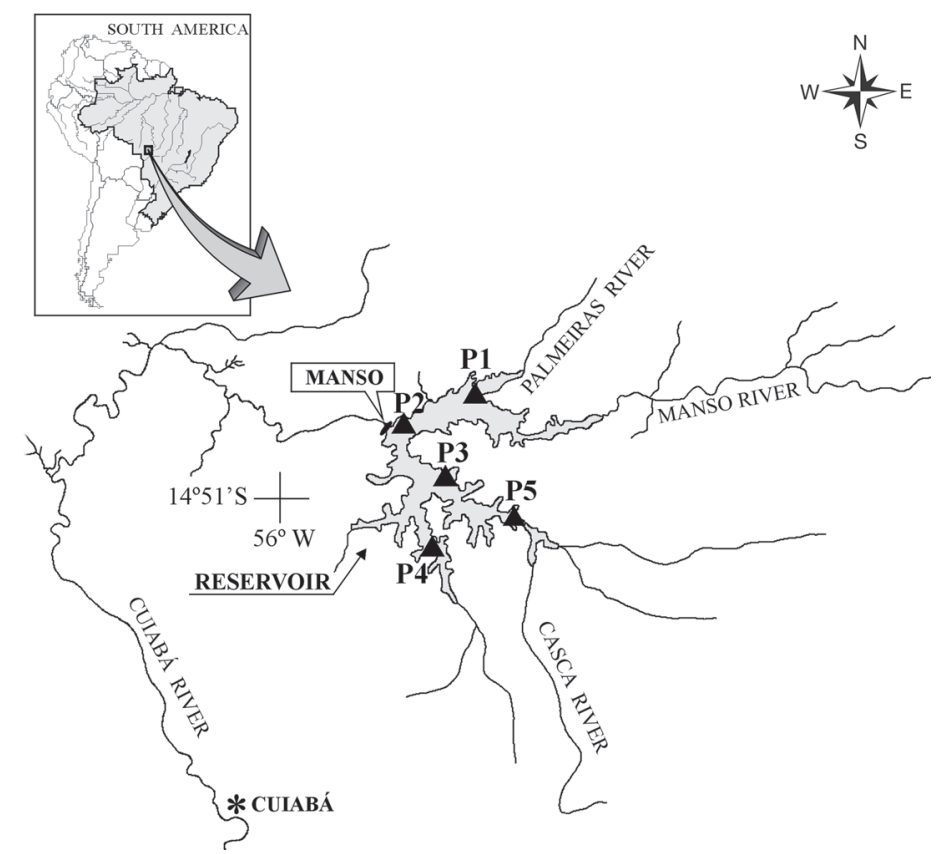

Fig. 1. Locations of the sampling points (triangles=P1, P2, P3, P4 and P5) along the Cuiabá and Manso river basins in the state of Mato Grosso, Brazil between March 2000 and March 2004.

Ahlstrom \& Ball (1954) and modified by Nakatani et al. (2001). Each period was described based on the degree of development and occurrence of major morphological events, with representative individuals illustrated using a camera lucida. Individuals used in this research have been deposited in the Ichthyological Collection of the Center for Research in Limnology, Ichthyology and Aquaculture (Nupélia) at the State University of Maringá (Universidade Estadual de Maringá - UEM), Paraná, Brazil (NUP 16905 to NUP 16908 and NUP 13676).

For the morphological characterization of embryonic development, the following morphometric variables were measured (in $\mathrm{mm}$ ) using a stereoscope equipped with an ocular micrometer: egg diameter (EgD), yolk diameter (YD) and perivitelline space (PS), with the latter categorized as narrow, moderate, large or very large based on its share of the total egg volume (Nakatani et al., 2001). For both YD and PS, the horizontal diameter was defined as the major axis corresponding to the distance between the animal and vegetal poles, and the vertical diameter was defined as the axis with the smallest diameter. For the larvae and juveniles, the following parameters were also measured (in mm) (according to Ahlstrom, Butler, \& Sumida, 1976; Nakatani et al., 2001): standard length (SL), snout length (SnL), eye diameter (EyD), head height (HH), head length (HL) body height $(\mathrm{BH})$, pre-pectoral $(\mathrm{SPcF})$, pre-pelvic (SPIF), pre-dorsal (SDF) and preanal (SAF) fin distances. Meristic characterizations were performed by counting, when possible, the number of pre- and post-anal myomeres and number of rays in the pectoral $(\mathrm{Pc})$, pelvic (Pl), dorsal (D) and anal (A) fins. The body ratios for EyD, BH and HL were determined using the categories proposed by Leis \& Trnski (1989).

Growth models: To identify potential ontogenic variations during the larval and juvenile periods, the morphometric variables (dependent variables) were plotted against a standard and the HL (explanatory variables), and their relationships were analyzed using 
various regression models (Kováč, Copp, \& Francis, 1999). First, we tested the hypothesis that body ratio development is continuously isometric using a simple linear regression model. In addition, we also tested two alternative hypotheses: gradual allometric growth by using a quadratic regression analysis and discontinuous isometric growth by using a piecewise linear regression analysis, which is characterized by breakpoints reflecting divergent growth rates. The optimal models for each morphometric variable relative to body and head size were determined using $\mathrm{F}$ tests (Sokal $\&$ Rohlf, 1981). The significance level for the analyses was $\mathrm{p}<0.05$.

\section{RESULTS}

In total, 60 eggs (20 in the early cleavage, 20 in the early embryo and 20 in the tail-free stage), 88 larvae (20 in the yolk-sac, 48 in the flexion and 20 in the post-flexion stage) and 21 juveniles were analyzed. Each period is described below and illustrated in figure 2 and figure 3. Results related to morphometry, meristic counts and body ratios for the different periods are shown (Table 1, Table 2 and Table 3 ), and the results from the regression analyses of larval and juvenile growth are shown in table 4.

Embryonic period: In general, the eggs were yellow (apart from the internal dendritic pigmentation throughout the yolk) and oval shaped, had narrow PSs and lacked oil droplets and mucosal outer membranes (Fig. 2a and Fig. 2c). Embryos in the final stage of development were not found among the analyzed samples.

Early cleavage stage: The eggs had a mean horizontal diameter of $2.05 \mathrm{~mm}$ and vertical diameter of $1.63 \mathrm{~mm}$ (Table 1). The PSs ranged from narrow to moderate, with mean diameters (relative to the egg) of $6.89 \%$ horizontally and $4.86 \%$ vertically. In most cases, the egg membranes were oval shaped, which was similar to the shape of the yolk (Fig. 2a).
A

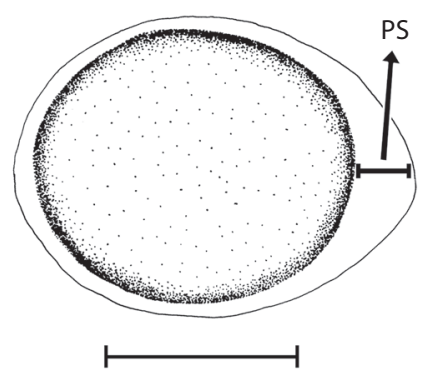

B

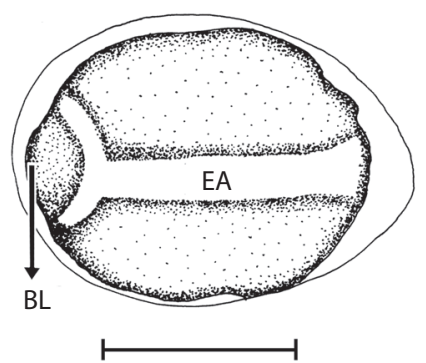

C

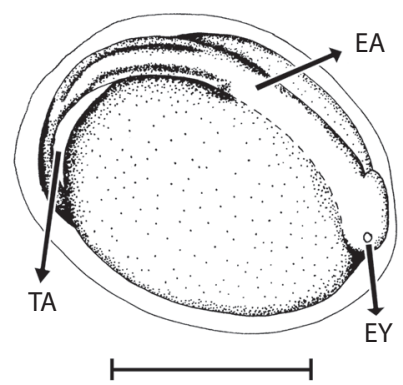

Fig. 2. Embryonic development of S. pappaterra collected from the Cuiabá and Manso river basins in the state of Mato Grosso, Brazil between March 2000 and March 2004. (A) Early Cleavage $(1.93 \mathrm{~mm}$ horizontal $\mathrm{EgD}$ and $1.67 \mathrm{~mm}$ vertical EgD); (B) Early Embryo (2.07mm horizontal EgD and $1.52 \mathrm{~mm}$ vertical $\mathrm{EgD})$; and $(\mathbf{C})$ Tail-Free $(2.15 \mathrm{~mm}$ horizontal $\mathrm{EgD}$ and $1.57 \mathrm{~mm}$ vertical $\mathrm{EgD})$. $\mathrm{EgD}=\mathrm{egg}$ diameter, $\mathbf{P S}=$ perivitelline space, $\quad \mathbf{B L}=$ blastopore, $\mathbf{E A}=$ embryonic axis, $\mathbf{T a}=$ tail, $\mathbf{E} \mathbf{y}=$ eye, $\mathbf{S c a l e}=1 \mathrm{~mm}$.

Early embryo stage: The eggs had a mean horizontal diameter of $2.01 \mathrm{~mm}$ and vertical diameter of $1.51 \mathrm{~mm}$ (Table 1). The PSs ranged from narrow to moderate, with mean diameters (relative to the egg) of $9.04 \%$ horizontally and $5.54 \%$ vertically. Within the yolk, formation of the embryonic axis was evident, and it extended from one pole to the other in the form of a continuous strip that bifurcated around the blastopore (Fig. 2b). 
TABLE 1

Minimum (Min), maximum (Max), mean (X) and standard deviation (SD) values for the length (mm) and perivitelline space ratios (\%) of the morphometric variables of the analyzed S. pappaterra eggs

\begin{tabular}{lcccccc}
\hline \multirow{2}{*}{\multicolumn{1}{c}{ Variables (mm) }} & \multicolumn{2}{c}{$\mathrm{EC}(\mathrm{n}=20)$} & \multicolumn{2}{c}{$\mathrm{EE}(\mathrm{n}=20)$} & \multicolumn{2}{c}{$\mathrm{TF}(\mathrm{n}=20)$} \\
& Min/Max & $\mathrm{X} \pm \mathrm{SD}$ & $\mathrm{Min} / \mathrm{Max}$ & $\mathrm{X} \pm \mathrm{SD}$ & $\mathrm{Min} / \mathrm{Max}$ & $\mathrm{X} \pm \mathrm{SD}$ \\
\hline Egg diameter (horizontal) & $1.93-2.18$ & $2.05 \pm 0.07$ & $1.93-2.15$ & $2.01 \pm 0.06$ & $1.98-2.28$ & $2.07 \pm 0.07$ \\
Egg diameter (vertical) & $1.55-1.75$ & $1.63 \pm 0.05$ & $1.40-1.68$ & $1.51 \pm 0.07$ & $1.25-1.70$ & $1.53 \pm 0.09$ \\
Vitellus diameter (horizontal) & $1.43-2.13$ & $1.81 \pm 0.15$ & $1.58-2.70$ & $1.78 \pm 0.22$ & $1.50-1.88$ & $1.67 \pm 0.09$ \\
Vitellus diameter (vertical) & $1.38-1.68$ & $1.50 \pm 0.07$ & $1.30-1.63$ & $1.41 \pm 0.08$ & $1.05-1.60$ & $1.38 \pm 0.11$ \\
Perivitelline space (horizontal) & $0.03-0.21$ & $0.11 \pm 0.05$ & $0.04-0.28$ & $0.14 \pm 0.05$ & $0.05-0.23$ & $0.19 \pm 0.04$ \\
Perivitelline space (vertical) & $0.01-0.75$ & $0.11 \pm 0.15$ & $0.00-0.09$ & $0.05 \pm 0.03$ & $0.00-0.14$ & $0.07 \pm 0.04$ \\
PS/EgD (\%) (horizontal) & $0.00-15.48$ & $6.89 \pm 4.05$ & $2.56-13.92$ & $9.04 \pm 3.21$ & $3.66-15.66$ & $11.23 \pm 3.76$ \\
PS/EgD (\%) (vertical) & $0.00-10.94$ & $4.86 \pm 2.70$ & $0.00-15.25$ & $5.54 \pm 3.55$ & $0.00-14.06$ & $9.15 \pm 2.85$
\end{tabular}

$\mathbf{n}=$ number of eggs analyzed, $\mathbf{E C}=$ Early Cleavage, $\mathbf{E E}=$ Early Embryo, $\mathbf{T F}=$ Tail-Free, $\mathbf{P S}=$ perivitelline space, $\mathbf{E g D}=\mathrm{egg}$ diameter.

Tail-free stage: The eggs had a mean horizontal diameter of $2.07 \mathrm{~mm}$ and vertical diameter of $1.53 \mathrm{~mm}$ (Table 1). The PSs ranged from narrow to moderate, with mean diameters of $11.23 \%$ horizontally and $9.15 \%$ vertically. At this stage, it is possible to observe a distinction between the body and head of the larva along the embryonic axis. The unpigmented forming eyes, notochord and punctate pigmentation within the posterior caudal region can also be observed (Fig. 2c). In the final phase of this stage, the caudal region begins to separate from the yolk, although it remains attached.

Larval period: None of the larvae examined were in the pre-flexion stage; other stages are described below.

Yolk-sac stage: In this stage, the SL ranged from $2.00 \mathrm{~mm}$ to $4.15 \mathrm{~mm}$ (Fig. 3a) (Table 2). Although it is possible to observe slight flexion of the notochord, the hypural bones have not yet formed. The yolk sac features internal dendritic pigmentation and is relatively large compared with the size of the larva. The eyes are elliptical and partially pigmented, and they do not undergo further shape changes during development. The mouth and anus are closed, and the snout does not yet exhibit a differentiated nasal aperture.
Within the head, the formation of bones can be observed, particularly the opercular bones, as well as two pairs of spherical adhesive glands. The pectoral fin bud is also evident at this stage, located superiorly to the yolk sac near the head. The 'finfold' surrounds the body longitudinally from the post-cephalic dorsal region to the posterior ventral margin of the yolk sac. Dendritic pigmentation is concentrated near the adhesive glands and dispersed throughout the yolk sac and in two bands of punctate pigmentation within the dorsal and ventral regions of the body. The total number of myomeres ranges from 24 to 31 (11 to 20 pre-anal and 12 to 16 post-anal) during this stage.

Flexion stage: The analyzed larvae were between $4.30 \mathrm{~mm}$ and $5.75 \mathrm{~mm}$ (Fig. $3 \mathrm{~b}$ and Fig. 3c) (Table 2). The yolk is completely absorbed by approximately $5.30 \mathrm{~mm}$ SL. At the end of this stage, the digestive system is well developed, with the mouth in a terminal position and anus open. The elliptical eyes are fully pigmented. Adhesive glands can be observed at the beginning of this stage, with a larger pair in the dorsal region of the head and smaller pair situated roughly between the eyes. The opening of the operculum and nostrils (simple) is observed at the end of this stage at approximately $5.50 \mathrm{~mm}$ SL. Initially, the finfold has the 

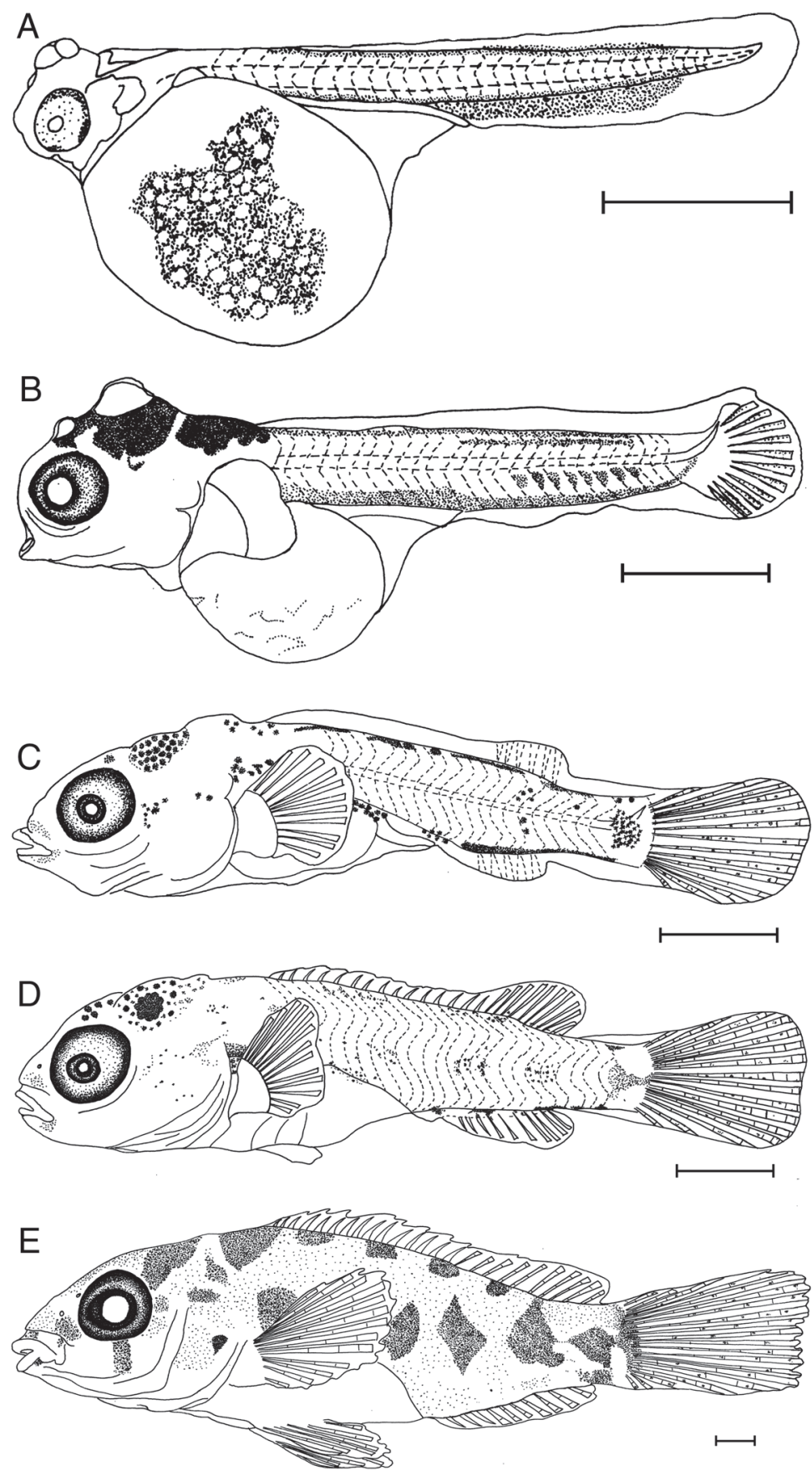

Fig. 3. Early development of $S$. pappaterra collected from the Cuiabá and Manso river basins in the state of Mato Grosso, Brazil between March 2000 and March 2004. (A) yolk-sac (4.05mm SL); (B) early flexion (5.3mm SL); (C) final flexion (7mm SL); (D) post-flexion (8.08mm SL); and (E) juvenile (18.4mm SL). Scale $=1 \mathrm{~mm}$. 
TABLE 2

Minimum (Min), maximum (Max), mean (X) and standard deviation (SD) values for the length (mm) of the morphometric and meristic variables obtained for the larvae and juvenile $S$. pappaterra individuals

\begin{tabular}{|c|c|c|c|c|c|c|c|c|}
\hline \multirow{3}{*}{$\begin{array}{l}\text { Variables } \\
(\mathrm{mm})\end{array}$} & \multicolumn{6}{|c|}{ Larval Period } & \multirow{2}{*}{\multicolumn{2}{|c|}{$\begin{array}{c}\text { Juvenile Period } \\
\qquad J(n=20)\end{array}$}} \\
\hline & \multicolumn{2}{|c|}{$Y S(n=20)$} & \multicolumn{2}{|c|}{ FL $(n=20)$} & \multicolumn{2}{|c|}{$P F(n=20)$} & & \\
\hline & $\operatorname{Min} / \operatorname{Max}$ & $\mathrm{X} \pm \mathrm{SD}$ & $\operatorname{Min} / \operatorname{Max}$ & $\mathrm{X} \pm \mathrm{SD}$ & $\operatorname{Min} / \operatorname{Max}$ & $\mathrm{X} \pm \mathrm{SD}$ & $\operatorname{Min} / \operatorname{Max}$ & $\mathrm{X} \pm \mathrm{SD}$ \\
\hline SL & $2.00-4.15$ & $3.91 \pm 0.46$ & $4.30-5.75$ & $5.08 \pm 0.40$ & $6.34-10.25$ & $7.16 \pm 0.97$ & $10.29-24.57$ & $15.42 \pm 3.79$ \\
\hline $\mathrm{HH}$ & $0.60-0.80$ & $0.70 \pm 0.07$ & $0.83-1.57$ & $1.24 \pm 0.18$ & $1.60-2.90$ & $1.95 \pm 0.31$ & $2.85-6.29$ & $4.36 \pm 0.93$ \\
\hline HL & $0.43-0.60$ & $0.51 \pm 0.05$ & $0.75-1.95$ & $1.45 \pm 0.38$ & $2.16-3.83$ & $2.51 \pm 0.38$ & $3.67-9.00$ & $5.51 \pm 1.27$ \\
\hline $\mathrm{SnL}$ & $0.03-0.18$ & $0.10 \pm 0.06$ & $0.05-0.44$ & $0.21 \pm 0.11$ & $0.30-0.67$ & $0.46 \pm 0.11$ & $0.72-3.86$ & $1.52 \pm 0.75$ \\
\hline EyD & $0.15-0.38$ & $0.31 \pm 0.05$ & $0.13-0.74$ & $0.56 \pm 0.14$ & $0.73-1.10$ & $0.92 \pm 0.09$ & $1.24-2.75$ & $1.83 \pm 0.37$ \\
\hline $\mathrm{BH}$ & $1.48-1.68$ & $1.57 \pm 0.05$ & $1.17-1.74$ & $1.46 \pm 0.15$ & $1.67-3.00$ & $1.99 \pm 0.36$ & $3.10-7.71$ & $4.93 \pm 1.10$ \\
\hline $\mathrm{SPcF}$ & $0.63-0.73$ & $0.68 \pm 0.07$ & $1.13-2.07$ & $1.80 \pm 0.27$ & $2.25-3.75$ & $2.60 \pm 0.36$ & $3.83-9.14$ & $5.65 \pm 1.20$ \\
\hline SPIF & & & & & $2.47-4.08$ & $2.82 \pm 0.38$ & $4.20-8.57$ & $5.92 \pm 1.09$ \\
\hline SDF & & & & & $2.47-3.83$ & $2.86 \pm 0.35$ & $3.92-8.29$ & $5.55 \pm 1.09$ \\
\hline SAF & & & & & $2.64-9.40$ & $4.80 \pm 1.32$ & $6.43-16.71$ & $10.07 \pm 2.30$ \\
\hline \multicolumn{9}{|l|}{ Myomere } \\
\hline Total & $24.00-31.00$ & $29.00 \pm 2.24$ & $22.00-30.00$ & $26.04 \pm 1.79$ & $24-29$ & $26.32 \pm 1.16$ & & \\
\hline Pre-anal & $11.00-20.00$ & $14.22 \pm 1.96$ & $9.00-15.00$ & $12.33 \pm 1.48$ & $12-16$ & $14.05 \pm 0.94$ & & \\
\hline Post-anal & $12.00-16.00$ & $15.05 \pm 1.08$ & $12.00-16.00$ & $13.69 \pm 1.24$ & $10-14$ & $12.16 \pm 1.12$ & & \\
\hline \multicolumn{9}{|l|}{ Rays } \\
\hline $\mathrm{Pc}$ & & & $6.00-12.00$ & $9.04 \pm 1.80$ & $10-14$ & $12.20 \pm 0.95$ & $13-16$ & $14.76 \pm 0.62$ \\
\hline $\mathrm{Pl}$ & & & & & $5-6$ & $5.71 \pm 0.49$ & 4-8 & $5.43 \pm 1.08$ \\
\hline D & & & & & $8-12$ & $9.75 \pm 1.45$ & $8-10$ & $9.71 \pm 0.56$ \\
\hline $\mathrm{A}$ & & & & & $6-8$ & $6.9 \pm 0.45$ & $5-8$ & $6.48 \pm 0.81$ \\
\hline
\end{tabular}

$\mathbf{n}=$ number of individuals analyzed, $\mathbf{Y S}=$ yolk-sac, $\mathbf{F L}=$ flexion, $\mathbf{P F}=$ post-flexion, $\mathbf{J}=$ juveniles, $\mathbf{S L}=$ standard length, $\mathbf{H H}=$ head height, $\mathbf{H L}=$ head length, $\mathbf{S n L}=$ snout length, $\mathbf{E y D}=$ eye diameter, $\mathbf{B H}=$ body height, $\mathbf{S P c F}=$ snout-pectoral fin distance, $\mathbf{S P I F}=$ snout-pelvic fin distance, $\mathbf{S D F}=$ snout-dorsal fin distance, $\mathbf{S A F}=$ snout-anal fin distance, $\mathbf{P c}=$ pectoral, $\mathbf{P I}=$ pelvic, $\mathbf{D}=$ dorsal, $\mathbf{A}=$ anal. Missing measurements are a result of incompletely developed larvae.

same pattern as in the previous stage; however, the finfold becomes partially absorbed during development, outlining the dorsal and anal fins, which begin to show rays at approximately $5.58 \mathrm{~mm}$ SL. With respect to the caudal fin, rays begin to form at $4.7 \mathrm{~mm} \mathrm{SL}$, and beginning at $5.25 \mathrm{~mm} \mathrm{SL}$, the rays begin to segment. The first rays (6 to 12 rays) of the pectoral fin are visible at approximately $5.67 \mathrm{~mm}$ SL. Development of the pelvic fin bud begins at approximately $5.75 \mathrm{~mm}$ SL. Dendritic pigments are dispersed throughout the yolk sac, whereas punctate pigments are concentrated near the adhesive glands and median longitudinal lines of the dorsal and ventral regions of the larvae. Compared to the previous stage, these pigment lines become discontinuous over the course of development. At the end of this stage, concentrations of pigment appear in the upper portion of the head, inter-orbital region and above the stomach and caudal peduncle; punctate pigment can also be observed on the mouth and operculum. The total number of myomeres varies from 22 to 30 ( 9 to 15 pre-anal and 12 to 16 post-anal) during this stage.

Post-flexion stage: The SL of the samples ranged from $6.34 \mathrm{~mm}$ to $10.25 \mathrm{~mm}$ (Fig. 3d) (Table 2). By this stage, the digestive system has formed (visible by transparency), and an anal opening is located medially to the body axis. The eyes are elliptical and pigmented, and the operculum is defined. Nasal apertures are simple. The finfold is fully absorbed, and 
the dorsal and anal fins have defined shapes, with the onset of ray segmentation beginning at approximately $7.0 \mathrm{~mm}$ SL. All rays of the caudal fin are segmented. The dorsal fin exhibits between XIII to XV spines and 10 to 12 rays, whereas the anal fin has III spines and 6 to 8 rays. From $6.67 \mathrm{~mm}$ SL onward, the pectoral fin exhibits between 10 and 14 fully segmented rays. At the beginning of this stage, the pelvic fin is present as a bud, whereas after $7.76 \mathrm{~mm}$ $\mathrm{SL}$, rays begin to form (varying between 5 and 6) with early segmentation. Some regions of punctate pigmentation can be observed around the mouth, between the eyes and in the posterior dorsal region of the head, lobes of the head and operculum region. The punctate pigmentation pattern of the body changes over the course of development. At the beginning of this stage, 4 to 6 spots of pigment concentration are present near the dorsal region, and 4 to 5 spots are present along the body (above the stomach near the caudal region). At the end of this stage, the pigment concentration above the stomach becomes elongated longitudinally, and the remaining spots exhibit rounded shapes. Because of increased body mass and pigmentation, it was not possible to count myomeres during this stage.

Juvenile period: The SL of the samples ranged from $10.29 \mathrm{~mm}$ to $24.57 \mathrm{~mm}$ (Fig. 3e) (Table 2). The eyes are elliptical, and the nasal apertures are simple. In this period, individuals already possess ctenoid scales, and all of the morphological features are fully formed and adult-like. The dorsal fin exhibits between XIV to XVI spines and 8 to 10 rays, the anal fin exhibits between III to IV spines and 8 to 10 rays, the pectoral fin exhibits between 13 to 16 rays, and the pelvic fin exhibits I spine and 4 to 8 rays. The pigmentation pattern is similar to that observed during the post-flexion stage, with the addition of increased numbers of chromatophores and the formation of transverse pigment spots throughout the body.

Body ratios: Three variables were analyzed over the course of ontogenic development and standardized relative to the HL. Head height $(\mathrm{HH})$ decreased during development and ranged from $138.03 \%$ to $79.49 \%$. Snout length $(\mathrm{SnL})$ decreased between the yolk-sac and flexion stages $(20.74 \%$ and $13.95 \%$, respectively) and increased during the two remaining stages $(18.40 \%$ and $26.91 \%$, respectively). Eye diameter (EyD) increased during each larval stage, ranging from moderate to large (25.00\% to $76.47 \%$ during yolk-sac; $28.70 \%$ to $40.57 \%$ during post-flexion; and $30.56 \%$ to $38.10 \%$ during juvenile); however, its proportions decreased over the course of development (mean of $61.86 \%$ during yolk-sac and $33.44 \%$ during juvenile) (Table 3 ).

Six other variables were analyzed relative to SL. Head length (HL) showed an increase in relation to SL, ranging from small during the yolk-sac stage to large during the post-flexion stage $(13.85 \%$ to $37.07 \%$, respectively). Body height $(\mathrm{BH})$ remained moderate to very large during the yolk-sac stage (36.88\% to $77.5 \%)$ and moderate during the flexion through juvenile stages (varying between $28.96 \%$ and $32.02 \%)$. Snout-pectoral fin distance ( $\mathrm{SPcF}$ ) increased throughout all of the stages, ranging from $16.48 \%$ to $37.07 \%$, whereas SP1F distance did not significantly change $(39.52 \%$ during post-flexion vs. $39.07 \%$ during juvenile). Decreases in the SDF and SAF distances were observed ( $40.01 \%$ to $36.44 \%$ and $67.31 \%$ to $65.69 \%$, respectively) (Table 3 ).

Growth models: With respect to the body growth analyses, SnL and $\mathrm{HH}$ showed discontinuous isometric growth (piecewise linear regression) relative to $\mathrm{HL}$ (from $0.50 \mathrm{~mm}$ and $1.87 \mathrm{~mm}$, respectively) during development (Table 4); in particular, we observed a change in growth rate during the post-flexion stage (Appendix). Based on the slopes of the data, these variables showed higher growth rates after the breakpoint, increasing from $0.17 \mathrm{~mm}$ to $0.37 \mathrm{~mm}$ for $\mathrm{SnL}$ and from $0.54 \mathrm{~mm}$ to $0.75 \mathrm{~mm}$ for HL (Table 4). Eye diameter (EyD) showed continuous isometric growth (linear regression), meaning that EyD showed constant growth throughout the course of development. 
TABLE 3

Minimum (Min), maximum (Max), mean (X) and standard deviation (SD) values for the body ratio (\%) of the morphometric and meristic variables from the analyzed $S$. pappaterra individuals

\begin{tabular}{lcccccccc} 
& \multicolumn{9}{c}{ Larval Period } & \multicolumn{3}{c}{ Juvenile Period } \\
Relations & \multicolumn{2}{c}{ YS $(\mathrm{n}=20)$} & \multicolumn{2}{c}{ FL $(\mathrm{n}=20)$} & \multicolumn{2}{c}{ FP $(\mathrm{n}=20)$} & \multicolumn{2}{c}{$\mathrm{J}(\mathrm{n}=20)$} \\
& $\mathrm{Min} / \mathrm{Max}$ & $\mathrm{X} \pm \mathrm{SD}$ & $\mathrm{Min} / \mathrm{Max}$ & $\mathrm{X} \pm \mathrm{SD}$ & $\mathrm{Min} / \mathrm{Max}$ & $\mathrm{X} \pm \mathrm{SD}$ & $\mathrm{Min} / \mathrm{Max}$ & $\mathrm{X} \pm \mathrm{SD}$ \\
$\mathrm{HH} / \mathrm{HL}$ & $109.09-170.59$ & $138.03 \pm 17.8$ & $64.99-130.00$ & $88.87 \pm 15.3$ & $70.68-86.46$ & $77.70 \pm 4.2$ & $69.84-93.96$ & $79.49 \pm 5.4$ \\
$\mathrm{SnL} / \mathrm{HL}$ & $4.76-41.18$ & $20.74 \pm 12.1$ & $4.31-23.86$ & $13.95 \pm 4.9$ & $12.50-26.68$ & $18.40 \pm 3.6$ & $18.78-62.89$ & $26.91 \pm 9.5$ \\
$\mathrm{EyD} / \mathrm{HL}$ & $25.00-76.47$ & $61.86 \pm 11.1$ & $13.89-50.00$ & $39.20 \pm 5.7$ & $28.70-40.57$ & $37.01 \pm 2.8$ & $30.56-38.10$ & $33.44 \pm 1.9$ \\
$\mathrm{HL} / \mathrm{SL}$ & $10.49-25.61$ & $13.85 \pm 3.5$ & $16.07-36.82$ & $28.13 \pm 5.6$ & $31.83-37.97$ & $35.06 \pm 1.6$ & $24.54-38.98$ & $35.96 \pm 3.2$ \\
$\mathrm{BH} / \mathrm{SL}$ & $36.88-77.50$ & $41.27 \pm 8.9$ & $22.03-37.09$ & $28.96 \pm 4.6$ & $24.88-30.70$ & $27.81 \pm 1.8$ & $24.05-35.00$ & $32.02 \pm 2.5$ \\
$\mathrm{SPcF} / \mathrm{SL}$ & $15.06-17.90$ & $16.48 \pm 2.0$ & $29.22-39.26$ & $34.74 \pm 2.3$ & $33.58-42.54$ & $36.43 \pm 1.8$ & $26.38-46.18$ & $37.07 \pm 3.7$ \\
$\mathrm{SPIF} / \mathrm{SL}$ & - & - & - & - & $35.57-44.08$ & $39.52 \pm 1.9$ & $28.77-49.58$ & $39.07 \pm 4.4$ \\
$\mathrm{SDF} / \mathrm{SL}$ & - & - & - & - & $37.00-43.54$ & $40.01 \pm 1.9$ & $27.00-39.69$ & $36.44 \pm 2.9$ \\
$\mathrm{SAF} / \mathrm{SL}$ & - & - & - & - & $40.62-140.30$ & $67.31 \pm 18.5$ & $47.24-71.88$ & $65.69 \pm 5.1$ \\
\hline
\end{tabular}

$\mathbf{n}=$ number of individuals analyzed, $\mathbf{Y S}=$ yolk-sac, $\mathbf{F L}=$ flexion, $\mathbf{P F}=$ post-flexion, $\mathbf{J}=$ juveniles, $\mathbf{H H}=$ head height, $\mathbf{H L}=$ head length, $\mathbf{S n L}=$ snout length, $\mathbf{E y D}=$ eye diameter, $\mathbf{B H}=$ body height, $\mathbf{S L}=$ standard length, $\mathbf{S P c F}=$ snout-pectoral fin distance, $\mathbf{S P I F}=$ snout-pelvic fin distance, $\mathbf{S D F}=$ snout-dorsal fin distance, $\mathbf{S A F}=$ snout-anal fin distance. Missing measurements are because of incompletely developed larvae.

TABLE 4

Mathematic and statistical values of the linear (L), quadratic (Q) and piecewise linear (S) regression analyses of the morphometric variables obtained relative to the head and standard length of the S. pappaterra larvae

\begin{tabular}{|c|c|c|c|c|c|c|c|c|c|c|c|c|c|}
\hline \multirow{2}{*}{ Relation } & \multicolumn{3}{|c|}{$\mathrm{R}^{2}$} & \multicolumn{3}{|c|}{ F Test } & \multirow{2}{*}{ BM } & \multirow{2}{*}{$\mathrm{BP}$} & \multirow{2}{*}{ al } & \multirow{2}{*}{ b1 } & \multirow{2}{*}{ a2 } & \multirow{2}{*}{ b2 } & \multirow{2}{*}{$\mathrm{n}$} \\
\hline & $L$ & $Q$ & S & $Q / L$ & $S / Q$ & $S / L$ & & & & & & & \\
\hline $\mathrm{HH} / \mathrm{HL}$ & 0.98 & 0.97 & 0.99 & $-24.20 *$ & $95.12 *$ & $24.61^{*}$ & S & 1.87 & 0.54 & 0.46 & 0.75 & 0.23 & 109 \\
\hline $\mathrm{SnL} / \mathrm{HL}$ & 0.83 & 0.86 & 0.85 & $21.00^{*}$ & $-4.00 *$ & $7.99 *$ & S & 0.50 & 0.17 & -0.02 & 0.37 & -0.52 & 107 \\
\hline $\mathrm{EyD} / \mathrm{HL}$ & 0.98 & 0.98 & 0.98 & $-29.95^{*}$ & $49.92 *$ & 2.95 & $\mathrm{~L}$ & 0.83 & 0.29 & 0.16 & 0.30 & 0.20 & 108 \\
\hline HL/SL & 0.95 & 0.92 & 0.96 & $-29.55^{*}$ & $106.92 *$ & $23.78^{*}$ & S & 2.24 & 0.60 & -1.68 & 0.34 & 0.21 & 109 \\
\hline $\mathrm{BH} / \mathrm{SL}$ & 0.94 & 0.94 & 0.97 & -0.09 & $88.22 *$ & $44.03 *$ & S & 2.25 & 0.041 & 1.33 & 0.31 & 0.15 & 108 \\
\hline $\mathrm{SPcF} / \mathrm{SL}$ & 0.95 & 0.95 & 0.96 & 2.46 & $15.01 *$ & $9.02 *$ & S & 3.29 & 0.44 & -0.56 & 0.29 & 1.22 & 65 \\
\hline $\mathrm{SPIF/SL}$ & 0.93 & 0.94 & 0.96 & $10.15^{*}$ & $15.04 *$ & $14.52 *$ & S & 4.40 & 0.39 & 0.04 & 0.22 & 2.71 & 41 \\
\hline SDF/SL & 0.95 & 0.96 & 0.97 & $14.11^{*}$ & 2.45 & $8.56^{*}$ & Q & - & -0.005 & 0.45 & - & - & 41 \\
\hline SAF/SL & 0.88 & 0.89 & 0.94 & 1.30 & $28.99 *$ & $15.63^{*}$ & S & 7.50 & 0.649 & -0.10 & 0.36 & 5.02 & 41 \\
\hline
\end{tabular}

$\mathbf{R}^{2}=$ coefficient of determination, $\mathbf{B M}=$ best model, $\mathbf{B P}=$ breakpoint $(\mathrm{mm})$, a and $\mathbf{b}=$ regression parameters (a, slope coefficient; b, linear coefficient), $\mathbf{n}=$ number of individuals analyzed, $\mathbf{H H}=$ head height, $\mathbf{H L}=$ head length, $\mathbf{S n L}=$ snout length, $\mathbf{E y D}=$ =ye diameter, $\mathbf{S L}=$ standard length, $\mathbf{B H}=$ body height, $\mathbf{S P c F}=$ snout-pectoral fin distance, $\mathbf{S P I F}=$ snout-pelvic fin distance, $\mathbf{S D F}=$ snout-dorsal fin distance, $\mathbf{S A F}=$ snout-anal fin distance, $(*)=\mathrm{p}<0.05$, bold=values of the significant regressions.

For the variables related to SL, the results indicated that $\mathrm{HL}, \mathrm{BH}$ and the $\mathrm{SPcF}$, SP1F, and SAF distances showed discontinuous isometric growth during development (breakpoints $=2.24 \mathrm{~mm}, 2.25 \mathrm{~mm}, 3.29 \mathrm{~mm}$, $4.40 \mathrm{~mm}$ and $7.50 \mathrm{~mm}$, respectively) (Table 4 and Appendix). With the exception of $\mathrm{BH}$, which showed increased growth during the post-flexion stage, the other variables decreased relative to growth rate at the beginning of either the flexion (for HL and SP1F and SAF distances) or juvenile (for SP1F distance) stages. The SDF distance showed quadratic development, meaning that it showed variable growth 
that initially increased and then decreased (concave-down parabola, a1=-0.01) (Table 4 and Appendix).

\section{DISCUSSION}

The identification of ontogenic structural traits and determining their morphological changes during development is highly relevant to taxonomic studies involving fish eggs and larvae. These characteristics often provide significant information pertaining to the reproductive strategies of a species. For example, large eggs with narrow PS, such as those produced by $S$. pappaterra, are indicative of species with long larval development times (Vazzoler, 1996) and parental care (Nakatani et al., 2001). Among the cichlid species described thus far, it was not possible to define a pattern with respect to EgD. Substrate spawners (C. nigrofasciatum, Martinez, \& Murillo, 1987); H. nicaraguensis (Molina, 2011); A. rostratus (Molina, 2008); and Amphilophus alfari (Meek, 1907) (Molina, 2010) produce eggs with similar dimensions to those of $S$. pappaterra, with the eggs varying from $2.00 \mathrm{~mm}$ to $2.25 \mathrm{~mm}$ along the horizontal axis and from $1.55 \mathrm{~mm}$ to $1.72 \mathrm{~mm}$ along the vertical axis; C. dimerus (Meijide \& Guerrero, $2000)$ is an exception and produces smaller eggs $(1.65 \mathrm{~mm} \pm 0.05 \mathrm{~mm}$ horizontal diameter and $1.25 \mathrm{~mm} \pm 0.05 \mathrm{~mm}$ vertical diameter). With respect to mouth-brooders, the eggs of Oreochromis mossambicus (Peter, 1852) are significantly larger than those of $S$. pappaterra, with a horizontal diameter of $3.04 \mathrm{~mm} \pm 0.20 \mathrm{~mm}$ and vertical diameter of $2.19 \mathrm{~mm} \pm 0.16 \mathrm{~mm}$ (Holden $\&$ Bruton, 1992). Therefore, the dimensions of $S$. pappaterra eggs are more similar to those of previously characterized substrate spawners than mouth-brooders. According to Kuwamura and Mihigo (1988) mouth-brooders produce fewer eggs that are of a larger size than substrate-brooders, and their young begin exogenous feeding later and at a more developed stage than the young of substrate-brooders.

Within the family Cichlidae, internal pigmentation of the yolk during the embryonic period appears to be a reliable taxonomic characteristic of this group. For example, $A$. ocellatus, which was described by Nakatani et al. (2001) and Paes et al. (2011), shows strong pigmentation within the yolk sac from the embryonic period until full absorption, which is similar to what was observed for $S$. pappaterra; the same pigmentation occurs during the embryonic stages of the species C. gadovii (Cabrera et al. 1988)), C. dimerus (Meijide \& Guerrero, 2000) and Oreochromis niloticus (Linnaeus 1758) (Nakatani et al., 2001; Fujimura \& Okada, 2007), although the pigmentation is less intense.

Characterizing the shape and distribution of pigmentation is also widely used in taxonomic studies to identify larvae and juveniles (Nascimento \& Araújo-Lima, 1993; Meijide \& Guerrero, 2000; Godinho, Santos, \& Sato, 2003; Oliveira et al., 2012). In the cichlids A. ocellatus (Nakatani et al., 2001; Paes et al., 2011), O. niloticus (Nakatani et al., 2001; Fujimura \& Okada, 2007), C. nigroasciatum (Martinez \& Murillo, 1987), H. nicaraguensis (Molina, 2011) and S. pappaterra, the presence of dendritic pigments in the upper region of the head at the onset of the larval period appears to be a common trait. With respect to body pigmentation, $S$. pappaterra larvae differ from other species by the presence of pigmented regions in the dorsal and ventral regions. At the beginning of the juvenile period, S. pappaterra has 5 or 6 transverse spots, C. nigrofasciatum has 8 or 9 transverse spots (Martinez \& Murillo, 1987) and O. niloticus has 7 transverse spots (Nakatani et al., 2001; Fujimura \& Okada, 2007). In contrast, H. nicaraguensis does not have spots on its body and shows only a blotch on the caudal peduncle (Molina, 2011), whereas $A$. ocellatus shows intense pigmentation throughout its entire body as well as between the rays of its fins (Nakatani et al., 2001; Paes et al., 2011).

From an ecological perspective, pigmentation patterns may play protective roles against predation. Therefore, the absence of pigmentation on the bodies of larvae during early developmental stages suggests that they do not require camouflage, which is perhaps because 
they are cared for by their parents. However, as larvae continue to develop (post-flexion larvae and juveniles), pigmentation increases and bands appear, allowing larvae to camouflage themselves in their environment. For $A$. ocellatus, Machado-Allison (1987) observed that the larvae develop a highly disruptive pigmentation pattern in natural environments, which allows a perfect camouflage against predators when the larvae are hidden among macrophyte roots. Indeed, this behavior has been observed in larvae from a variety of species (e.g., Hoplias malabaricus, Hoplosternum littorale and Prochilodus lineatus), which has been described by Nakatani, Baumgartner and Cavicchioli (1997) and Nakatani, Bialetzki, Baumgartner, Sanches and Makrakis (2004).

With respect to larval development, a slight flexion of the notochord could be observed during the yolk-sac stage prior to the formation of the hypural bones in S. pappaterra. This phenomenon occurs extremely early and is unusual at this stage of development compared with other species. In addition, of the analyzed larvae, specimens in the pre-flexion stage were not found. Therefore, we believe that the preflexion stage in $S$. pappaterra may be short or even absent, which could be useful for identifying larval individuals.

The presence of adhesive glands is also an important characteristic for species identification. For example, $C$. dimerus (Meijide \& Guerrero, 2000), A. ocellatus (Nakatani et al., 2001; Paes et al., 2011) and H. nicaraguensis (Molina, 2011) exhibit three pairs of adhesive glands - two pairs on the upper region and a third on the frontal region of the head - whereas $S$. pappaterra possesses two pairs - a single pair of glands on the upper region of the head and another on the frontal region. Jones (1972) reported that the larvae of certain substratespawner species have three pairs of adhesive glands on their heads, whereas mouth-brooder larvae possess only rudimentary glands. Therefore, it is likely that the single pair of adhesive glands possessed by $S$. pappaterra is rudimentary, although this was not shown by our study. Within the family Cichlidae, S. pappaterra differs from O. niloticus (Nakatani et al., 2001; Fujimura \& Okada, 2007) by the lack of adhesive glands. In sedentary species and those with parental care, these organs play a protective role by preventing the dispersal of larvae, leading to better parental care. Meijide and Guerrero (2000) reported that within their first five days, $C$. dimerus larvae attach themselves to substrates using mucous secretions released by their adhesive organs. In S. pappaterra, these organs are likely used by larvae to attach themselves within the mouth of their parent when threatened.

Myomere number is another widely used characteristic in identifying fish larvae, which can be useful up to and including the species level. Nevertheless, this characteristic is rarely reported in studies, hindering the utility of comparative analyses. With respect to the larvae of described cichlids species, we could only find mention of this characteristic in the literature for A. ocellatus (Nakatani et al., 2001). Satanoperca pappaterra possesses 22 to 30 myomeres ( 9 to 15 pre-anal and 12 to 16 post-anal), which is similar to the 28 to 30 myomeres (13 to 14 pre-anal and 14 to 16 postanal) observed in A. ocellatus larvae. Therefore, the use of this trait for differentiating between these two species would only be effective if used in conjunction with other traits.

Analysis of the morphological ontogeny of $S$. pappaterra larvae and juveniles revealed that of seven of the nine variables considered (SnL, HH, HL, and BH as well as SPcF, SP1F and SAF distances) showed variable growth rates (i.e., breakpoints), particularly during the flexion and post-flexion stages and in juveniles. According to Kováč et al. (1999), a breakpoint can be considered significant if it is associated with certain morphological, physiological and/ or survival events. In this case, changes in head morphology during ontogenic development may reflect changes in the ecology of the species because this breakpoint (i.e., increase in growth rate) coincides with changes in the feeding habits of $S$. pappaterra, as described by Cassemiro, Rangel, Pelicice and Hahn (2008). 
Finally, with respect to body-related changes, these are likely associated with increased locomotion during development (Kováč et al., 1999). Furthermore, Gatz Jr. (1979) proposed that body height is inversely related to maximal water velocity and directly related to the ability to perform vertical maneuvers and rotate around the body axis. Therefore, the morphological development of $S$. pappaterra is consistent with the ecological requirements of this species, which primarily occur in structured lentic environments with aquatic macrophytes (Casatti, Mendes, \& Ferreira, 2003).

\section{ACKNOWLEDGMENTS}

The authors would like to thank the Agreement UEM/ Nupélia//Furnas Centrais Elétricas S.A. for their financial support and the Research Center on Limnology, Ichthyology and Aquaculture (Nupélia) for their logistical support. We would also like to thank the Program of Scientific Initiation (Programa de Iniciação Científica - PIC/UEM) and our friends at the laboratories of Ichthyology and Ichthyoplankton/Nupélia/UEM for their aid in the field and in the laboratory.

\section{RESUMEN}

Desarrollo temprano en el pez cíclido Satanoperca pappaterra (Perciformes: Cichlidae). La región Neotropical exhibe la mayor diversidad de peces en todo el mundo. Sin embargo, poco se sabe sobre el desarrollo temprano de las especies de peces de esta región. Para contribuir a este conocimiento, este estudio tuvo como objetivo describir morfológicamente las primeras etapas de desarrollo (huevos, larvas y juveniles) de $S$. pappaterra usando rasgos morfométricos y merísticos. Además de evaluar los cambios en las tasas de crecimiento en el desarrollo larval y juvenil, mediante el análisis de las relaciones entre los diferentes rasgos morfométricos utilizando modelos de regresión analíticos. Tanto los individuos juveniles y adultos con crías de incubación bucal se recogieron a lo largo de las cuencas de los ríos Cuiabá y Manso en el estado de Mato Grosso, Brasil, entre marzo 2000 y marzo 2004. Después de identificar los adultos, las crías se clasificaron de acuerdo a su etapa (embrionaria, período larval o juvenil), y diversas variables morfométricas y merísticas se midieron de forma individual (cuando fue posible). Los huevos de esta especie son de color amarillo, ovalados, muestran pigmentación dendrítica dentro de su yema, tienen espacios perivitelinos de tamaño pequeño a moderado y carecen de una membrana mucosa y gotas de aceite. Los diámetros horizontales y verticales de las yemas oscilaron entre $1.43-2.70 \mathrm{~mm}$ y $1.05-1.68 \mathrm{~mm}$, respectivamente. La longitud estándar del período larval varió de 4.30-7.16mm, y la longitud estándar del período juvenil varió entre 10.29$24.57 \mathrm{~mm}$. Las larvas exhibieron sacos vitelinos con pigmentación dendrítica interna y pigmentación puntiforme oscura en las regiones dorsal y ventral del cuerpo, mientras que se observaron manchas transversales irregulares a lo largo de los flancos durante el periodo juvenil. Órganos adhesivos solo estan presentes durante la etapa de saco vitelino y al comienzo de la etapa de flexión. La boca es terminal durante todas las etapas de desarrollo. El número de miomeros varió entre 22 y 29 (9 a 16 pre-anal y 10 a 16 post-anal), y los números máximos de radios de las aletas y espinas fueron los siguientes: dorsal, XVI+10; anal, IV+8; pectoral, 16; y pélvica, I+8. El análisis del crecimiento identificó periodos de cambios importantes en la morfología larval (es decir, la metamorfosis), especialmente durante las etapas de flexión y post-flexión y en los juveniles. Por lo tanto, el desarrollo morfológico de S. pappaterra es consistente con las exigencias ecológicas de esta especie, que se encuentran principalmente en ambientes de estructura léntica con macrófitos acuáticos.

Palabras clave: ontogenia, huevos, larvas, peces, incubación bucal, Río Paraguay.

\section{REFERENCES}

Ahlstrom, E. H., \& Ball, O. P. (1954). Description of eggs and larvae of jack mackerel (Trachurus symmetricus) and distribution and abundance of larvae in 1950 and 1951. Fisheries Bulletin, 56, 209-245.

Ahlstrom, E. H., Butler, J. L., \& Sumida, B. Y. (1976). Pelagic stromateoid fishes (Pisces, Perciformes) of the Eastern Pacific: kinds, distributions, and early life histories and observations of five of these from the northwest Atlantic. Bulletin of Marine Science, 26, 285-402.

Alves, F. C. M, Rojas, N. E. T., \& Romagosa, E. (2009). Reprodução do "ciclídeo-anão amazônico", Apistogramma cacatuoides, Hoedeman, 1951 (Perciformes: Cichlidae) em laboratório. Boletim do Instituto de Pesca, 35(4), 587-596.

Bialetzki, A., Sanches, P. V., Baumgartner, G., \& Nakatani, K. (1998). Caracterização morfológica e distribuição temporal de larvas e juvenis de Apareiodon affinis (Steindachner 1879) (Osteichthyes, Parodontidae) no alto do rio Paraná (PR). Revista Brasileira de Zoologia, 15(4), 1037-1047.

Cabrera, J., Murillo, R., \& Mora, M. (1988). Desarrollo embrionario, larval y del alevín de Cichlasoma dovii 
(Günther, 1864) (Pisces: Cichlidae). Revista de Biologia Tropical, 36(2B): 417-422.

Casatti, L., Mendes, H. F., \& Ferreira, K. M. (2003). Aquatic macrophytes as feeding site for small fishes in the Rosana Reservoir, Paranapanema River, Southeastern Brazil. Brazilian Journal of Biology, 63(2), 213-222.

Cassemiro, F. A. S., Rangel, T. F. L. V. B., Pelicice, F. M., \& Hahn, N. S. (2008). Allometric and ontogenetic patterns related to feeding of a neotropical fish, Satanoperca pappaterra (Perciformes, Cichlidae). Ecology of Freshwater Fish, 17, 155-164.

Fishelson, L. (1995). Cytological and morphological ontogenesis and involution of the thymus in cichlid fishes (Cichlidae, Teleostei). Journal of Morphology, 233, 175-190.

Fujimura, K., \& Okada, N. (2007). Development of the embryo, larva and early juvenile of Nile tilapia Oreochromis niloticus (Pisces: Cichlidae). Developmental staging system. Development, Growth and Differentiation, 49, 301-324.

Gatz Jr., A. J. (1979). Ecological morphology of freshwater stream fishes. Tulane Studies in Zoology and Botany, 21, 91-124.

Godinho, H. P., Santos, J. E., \& Sato, Y. (2003). Ontogênese larval de cinco espécies de peixes do São Francisco. In H. P. Godinho, \& A. L. Godinho (Eds.), Águas, peixes e pescadores do São Francisco das Minas Gerais (pp. 133-148). Belo Horizonte: PUC Minas.

Holden, K. K., \& Bruton, M. N. (1992). A life-history approach to the early ontogeny of the Mozambique tilapia Oreochromis mossambicus (Pisces, Cichlidae). South African Journal of Zoology, 27(4), 173-191.

Jones, A. J. (1972). The early development of substratebrooding cichlids with a discussion of a new system of staging. Journal of Morphology, 136, 255-272.

Korzelecka-Orkisz, A., Szalast, Z., Pawlos, D., Smaruj, I., Tañski, A., Szulc, J., \& Formicki, K. (2012). Early ontogenesis of the angelfish, Pterophyllum scalare Schultze, 1823 (Cichlidae). Neotropical Ichthyology, 10(3), 567-576.

Kovàc, V., Copp, G. H., \& Francis, M. P. (1999). Morphometry of the stone loach, Barbatula barbatula: do mensural characters reflect the species' life history thresholds? Environmental Biology of Fishes, 56, 105-115.

Kullander, S. O. (1998). A phylogeny and classification of the South American Cichlidae (Teleostei: Perciformes). In L. R. Malabarba, R. E. Reis, R. P. Vari, Z. M. S. Lucena, \& C. A. S. Lucena (Eds.), Phylogeny and classification of Neotropical fishes (pp. 461-498). Porto Alegre: Edipucrs.
Kullander, S. O. (2003). Family Cichlidae. In R. E. Reis, S. O. Kullander, \& C. J. Ferraris Jr. (Eds), Check list of the freshwater fishes of South and Central America (pp.605-654). Porto Alegre: Edipurcs.

Kuwamura, T., \& Mihigo, N. K. (1988). Early ontogeny of a substrate-brooding cichlid, Boulengerochromis microlepis, compared with mouthbrooding species in Lake Tanganyika. Physiology and Ecology Japan, $25,19-25$.

Leis, J. M., \& Trnski, T. (1989). The larvae of Indo-Pacific shorefishes. New South Wales University Press, Sydney and University Press of Hawaii, Honolulu.

Machado-Allison, A. (1987). Los peces de los llanos de Venezuela: un ensayo sobre su historia natural. Caracas: Universidad Central de Venezuela, Consejo de Desarrollo Científico y Humanístico.

Martínez, S. G. A., \& Murillo, S. R. E. (1987). Desarrollo larval de Cichlasoma nogrofasciatum (Günther), 1868 (Pisces: Cichlidae) em cultivos em laboratório. Revista de Biología Tropical, 35(1), 113-119.

Meijide, F. J., \& Guerrero, G. A. (2000). Embryonic and larval development of substrate-brooding cichlid Ciclhasoma dimerus (Heckel, 1840) under laboratory conditions. Journal of Zoology, 252, 481-493.

Molina, A. (2008). Desarrollo larval de Amphilophus rostratus (Gill 1877) (Pisces: Cichlidae) cultivados en laboratório. Brenesia, 70, 47-52.

Molina, A. (2010). Desarrollo larval de Amphilophus alfari (Meek 1907) (Pisces: Cichlidae) cultivados en laboratório. Brenesia, 73-74, 103-107.

Molina, A. (2011). Larval development of Hypsophrys nicaraguensis (Pisces: Cichlidae) under laboratory conditions. Revista de Biologia Tropical, 59(4), 1679-1684.

Nakatani, K., Agostinho, A. A., Baumgartner, G., Bialetzki, A., Sanches, P. V., Makrakis, M. C., \& Pavanelli, C. S. (2001). Ovos e larvas de peixes de água doce: desenvolvimento e manual de identificação. Maringá: EDUEM.

Nakatani, K., Baumgartner, G., \& Cavicchioli, M. (1997). Ecologia de ovos e larvas de peixes. In A. E. A. M. Vazzoler, A. A. Agostinho, \& N. S. Hahn (Eds.), A planície de inundação do Alto Rio Paraná: aspectos fisicos, biológicos e econômicos (pp. 281-306). Maringá: EDUEM.

Nakatani, K., Bialetzki, A., Baumgartner, G., Sanches, P. V., \& Makrakis, M. C. (2004). Temporal and spatial dynamics of fish eggs and larvae. In S. M. Thomaz, A. A. Agostinho, \& N. S. Hahn (Eds.), The upper Paraná river and its floodplain: physical aspects, ecology and conservation (pp. 293-308). Leiden: Backhuys Publishers. 
Nascimento, F. L., \& Araújo-Lima, C. A. R. M. (1993). Descrição de larvas de Psectrogaster amazonica e Potamorhina altamazonica (Curimatidae, Pisces) da Amazonia Central. Acta Amazonica, 23(4), 457-472.

Oliveira, F. G., Bialetzki, A., Gomes, L. C., Santin, M., \& Taguti, T. L. (2012). Desenvolvimento larval de Brycon hilarii (Characiformes, Characidae). Iheringia, Série Zoologia, 102(1), 62-70.

Paes, M. C. F., Makino, L. C., Vasquez, L. A., Fernandes, J. B., \& Nakaghi, L. S. O. (2011). Early development of Astronotus ocellatus under stereomicroscopy and scanning electron microscopy. Zygote, 20, 269-276.
Puigcerver, M. (2007). Evolución del patrón de coloración melánica em los primeros estadios de desarrollo de la mojarra, Archocentrus myrnae Loiselle, 1997 (Perciformes: Cichlidae). Orsis, 22, 35-44.

Ribbink, A. J. (1990). Alternative life-history styles of some African cichlid fishes. Environmental Biology of fishes, 28, 87-100.

Sokal, R. R., \& Rohlf, F. J. (1981). Biometry. The principles and practice of statistics in biological research. New York: W. H. Freenan and Company.

Vazzoler, A. E. A. M. 1996. Biologia da reprodução de peixes teleósteos: teoria e prática. Maringá: EDUEM; São Paulo: SBI. 


\section{APPENDIX}
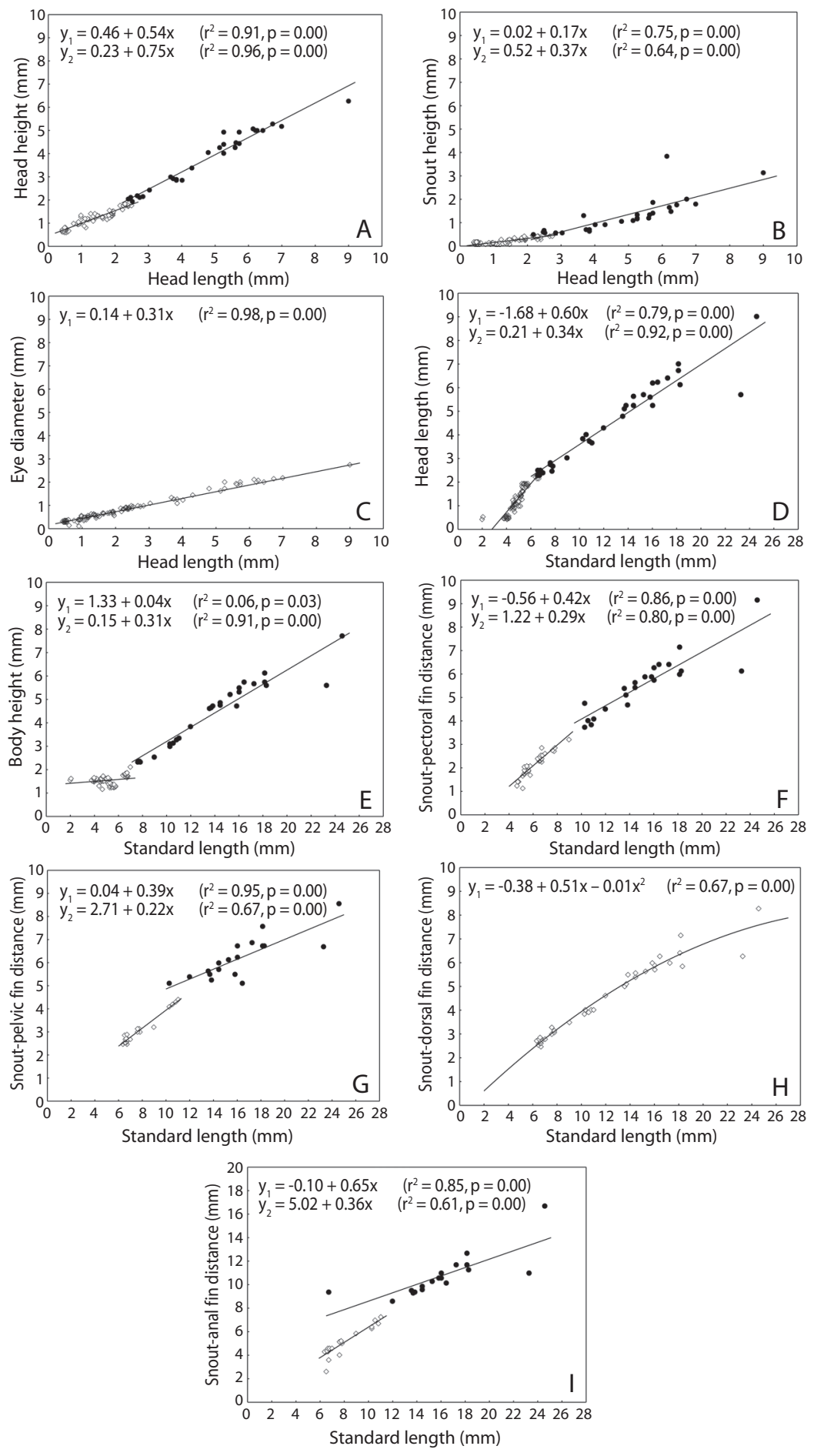
